\title{
NATO in 2030 and what the future will bring "Essential security, dynamic engagement"
}

\author{
A NATO 2030-ban és amit hoz a jövő \\ "Alapvető biztonság, dinamikus alkalmazás"
}

In the history of NATO, we had to respond to the challenges of a constantly changing world with regard to security risks. The new security challenges radically differ from the usual ones. Poverty, civil wars, and other conflicts and disasters can result in a wave of refugees to neighboring countries and regions. In these areas, emergency situations may emerge in security policy that the countries and regions concerned do not handle properly. Such emergencies may escalate or extend to nearby regions. To handle this, new skills need to be developed, and the correct answers can be given using the Bartlett theoretical model. The purpose of my study is to examine the future responsibilities of the Alliance and the processes supporting the fulfillment of these tasks, the strengthening the Alliance as a factor of lasting peace.

Keywords: NATO, challenges, Bartlett Model

A NATO története során folyamatosan változó világ biztonsági kihívásaira, kockázataira megfelelö válaszokat kellett adni. Az új biztonsági kihívások radikálisan el fognak térni a megszokottaktól. A szegénység, polgárháborúk és egyéb konfliktusok, katasztrófák menekülthullámot eredményezhetnek a szomszédos országokba és régiókba. Ezeken a területeken biztonsági veszélyhelyzetek alakulhatnak ki, amelyet ha az érintett országok, régiók nem megfelelöen kezelnek, akkor eszkalálódhatnak, kiterjedhetnek a környezetükben. Ehhez új képességeket kell kialakítani, amelyben a Bartlett elméleti

János Pataki, PhD candidate, National University of Public Service, Doctoral School of Military Sciences, ORCID: 0000-0002-3387-561 
JÁNOS PATAKI: NATO in 2030 and what the future will bring...

modell alkalmazásával adhatók adekvát válaszok. Tanulmányom célja, hogy megvizsgáljam a Szövetségre a jövőben háruló feladatokat, valamint a teljesítésüket szolgáló folyamatokat annak érdekében, hogy megerösítsék a Szövetséget a tartós béke tényezőjeként.

Kulcsszavak: NATO, kihívások, Bartlett-modell

\section{Premise}

NATO was established in 1949 as an opposition to the Soviet Union and was created under American leadership. Its main aim was to protect its members' sovereignty on the basis of the United Nations Charter. Its main role as a military alliance was to promote stability within the Alliance. In the last few decades, the political climate transformed, and consequently, the concept of security was heavily influenced. The Alliance has also transformed, and it pledged that it will respond it according to the emerging security challenges. ${ }^{2}$ Since its establishment, more and more European countries joined the NATO. For example, Hungary entered in 1999 along with Czech Republic and Poland. NATO was determined to provide security in Europe. Up to this date, the Alliance maintains stability and security in the European and Atlantic regions, and undergoes transformation, which would allow the Alliance to react to emerging challenges, such as terrorism ${ }^{3}$ or cyber warfare. ${ }^{4}$

One of the most important component of NATO is Article 5, the concept of collective defence: "an attack against one Ally is considered as an attack against all Allies". ${ }^{5}$ The concept of collective defence was laid down by the founding document in 1949, the Washington Treaty. Under the Treaty, member states are obliged to share the responsibility to carry out the tasks which are necessary in achieving security within the Alliance. ${ }^{6}$ It also demands that the states cooperate with regard to the rules and regulations in order to maintain security in the international system. Although, ideally, the states would use conflict as a last resort, the collective security model demands that, in case of external aggression, the states do not hesitate to retaliate. ${ }^{7}$ Historically, the Alliance not only decreased the risk of external aggression towards any member state, but it also contributed to the maintenance of peace between European countries who were in war several times in history. NATO simply created an environment where countries are heavily dependent on each other in terms of security, and can cooperate in the interest of their own wellbeing. ${ }^{8}$

NOETZEL-SCHREER 2009

JONES 2012, 3-8.

NATO Cyber Defence, 2016.

Collective defence - Article 5, 2019.

Collective defence - Article 5, 2019.

KUPCHAN-KUPCHAN 1995.

MORAN 2015. 


\section{New challenges}

NATO's new Strategic Concept acknowledges that the sole existence of nuclear warfare is a threat to the international community, therefore it is in its best interest to continue to share nuclear weapons with its non-nuclear members to deter a nuclear war. According to the classical deterrence theory, the dissemination of nuclear weapons would prevent a nuclear warfare, which is one of the main challenges NATO faces. ${ }^{9}$ Nuclear sharing shows that Allies face a major threat, in this case a nuclear war, and they devised a strategy based on a shared interest, to overcome a challenge. NATO's nuclear sharing policy was laid down in the Strategic Concept, with an emphasis on deterrence. "The fundamental purpose of Alliance nuclear forces is deterrence ${ }^{10}[\ldots]$ deterrence, based on an appropriate mix of nuclear and conventional capabilities, remains a core element of NATO's overall strategy."11 In this case, the Alliance takes a realist approach to the notion of collective security and defence. From a realist point of view, the international system is in the state of anarchy, states are more likely to recognize alliances as a tool to achieve their self-interest. From this perspective, nuclear sharing represents both balancing and defensive tactic. Those who oppose nuclear sharing argue that it violates international law, the Non-Proliferation Treaty (in force since 1970). They suggest that nuclear sharing violates Article I, which prohibits the sharing of nuclear weapons, and Article II, which prohibits obtaining such weapons. ${ }^{12}$ Non-nuclear nation-states who received nuclear weapons from the U.S. are strictly prohibited to use them, unless the U.S. President commands it during a war.

NATO's future engagement needs to be aware of the challenges and dangers that can significantly influence NATO's mission and operation. In my opinion, the statements of Huntington ${ }^{13}$ are still of great importance and National Intelligence Council (NIC) reports cannot be ignored. Based on these documents, I would like to outline the major trends that may occur in the future.

\section{NIC report Global Trends}

The Director of the NIC (National Intelligence Council) prepares a report entitled Global Trends - Paradox of Progress (2017) every four years, which looks forward to 15-20 years. The possible future trends proposed by the NIC report are supported by scientific studies and statistic.

The 2017 report outlines scenarios that can be predicted from current processes. According to the NIC report, governments will be in an increasingly difficult position

NOETZEL-SCHEER 2009, 211-226.

NATO's nuclear deterrence policy and forces é. n., 1.

NATO: Strategic Concepts.

NASSAUER 2001.

Huntington, Samuel Phillips (1927-2008), University Professor, Coordinator of Security Planning for the National Security Council. For more information: www.nytimes.com/2008/12/29/education/29huntington. html (Accessed: 15. 01. 2020) 
JÁNOS PATAKI: NATO in 2030 and what the future will bring...

due to the changing economic and technological environment in the next 18-20 years. The report points out that the international system which emerged after the Second World War is falling apart, as international peace and security are threatened by climate change and terrorism, and countries are finding it difficult to meet the growing needs of citizens.

The report outlines three scenarios that are not alternatives to each other, but are highly overlapping.

\section{"Islands" - national scenario ${ }^{14}$}

According to the report, the 2008 global economic crisis still has a significant effect on global economy. The report predicts that stagnation is likely until 2035. The isolation policy will be the characteristic trend in economy at state level. With regard to the population, social inequalities continue to rise, and the standard of living of the middle class will stagnate. Thus, losing masses will become more and more antiglobalists, putting politicians in a protectionist direction.

Global value chains and commercial networks will be transformed into regional or local (national) networks. One of the positive aspects of these processes is that the high pressure turns development towards robotics, 3-D printing and similar directions. However, the spread of the 'lock-in' trend is hampered by food and water scarcity caused and by climate change, which is particularly problematic in Africa and the Middle East.

Furthermore, due to the demographic changes, there are labor shortages in developed countries and more and more workers are coming out of economic interest from the Third World. According to the report, one possible outcome is illegal migration, and this will be a growing problem in developed countries.

\section{„Orbits"15 - Regional scenario}

In the next twenty years, the international power system will collapse, because it was formed prematurely after the Second World War. America may lose its hegemonic role.

By the mid-2020s, every medium power gets its own small area of influence in the region, where its own rules apply. China acquires East Asia, therefore entire rivers will be divided from other countries to irrigate lands of China, and artificial islands will be built to use them as military bases

The influence of Russia is expanding to Central Asia. Iran is trying to take the lead in the Middle East. However, each central powers have significant internal problems, social and economic conflicts. Therefore, they are trying to promote their power in international politics. 
Thus, trying to compromise will be very difficult in international politics. The middle powers begin to arm, but avoid open conflict. The next twenty years will be characterised by cyber attacks, propaganda campaigns, proxy wars, constant struggle with diplomatic and economic pressure, but an actual war is unlikeky to happen in the near future.

The $21^{\text {st }}$ century will not be the United States century... ${ }^{16}$

\section{"Communities"17 - international: city versus state}

An important statement of the report is that the next period will be characterised by the decline of the globalised economy and American hegemony. The conflicts and challenges will be difficult for the governing states around the world. Governments need to deal with more than one problem at a time:

- social dissatisfaction due to poor economic performance and unequal wealth distribution,

- terrorism (cyber and armed terrorism)

- ever-increasing number of refugees and conflicts,

- climate change,

- and power struggles.

The population are expecting more and more support from states, which, however, face more and more challenges, and their resources are scattered. Ideally, states should play a greater role to create an order in the midst of chaos, but in reality, this task is very costly in the short term and unlikely in the long run. There are two options for governments:

1. They will be able to gain even more control over the lives of citizens, moving towards a more authoritarian direction, giving up democracy more and more;

2. They surrender more and more areas of life to local, regional and urban authorities, NGOs, companies and other communities.

According to NIC analysts, the main characters may be leaders of increasingly populated cities in case of the second option. Besides climate change and robotisation, the population of big cities is increasing. Today, about half of the humanity live in towns, but by 2050 it will be two-thirds. The number of megapolises are also constantly increasing. In 2014, there were more than 28 million cities in the world, there will be 41 million by 2030, and twenty cities will have more than 5-10 million inhabitants.

Global Trends - Paradox of Progress 2017, 32.

Global Trends - Paradox of Progress 2017, 58-61. 


\section{According to Huntington}

The roots of the Western civilization stretches back to the 700 and 800 s. ${ }^{18}$ According to Huntington, three main groups account for Western civilization: Europeans, North Americans and Latin Americans, and it also include countries with European settlers such as Australia or New Zealand. Although during the $19^{\text {th }}$ century North America regarded itself as different from Europe, by the $20^{\text {th }}$ century its identity changed and it became closely related to Europe, in terms of identity. Regarding its development and distinct identity, Latin America was and is still very different from Europe and North America, and it is often considered as a separate civilization. ${ }^{19}$

Ultimately, in terms of politics, the notion of cultural identity gained a great importance in the Post-Cold War. The nation states continue to be the protagonists of world politics, which are already assembled according to civilisations. Huntington says the following:

- today's world is versatile and polygonal,

- there is a change currently in the balance of power between civilizations,

- a world order based on civilizations is developing,

- The West is increasingly confronted with other civilizations,

- Western civilization is not universal,

- democracies change.

The findings and statements of Huntington's book were published in 1996 and the scenarios outlined in the NIC report are consistent with it. I think it is important to highlight one of Huntington's thoughts that warns of the danger of "fissile societies", which already happened in Ukraine in 2014.

\section{NATO 2030, „Essential security, dynamic engagement”}

In my opinion, the future tasks and objectives of NATO were determined using the Bartlett model. The model helps to create a balance in strategic planning processes, taking into account the variables (objects, ends, strategy, resource, environment) on one level. Thus, it is possible to define the interaction between the key variables and help to overcome the inevitable tensions between these variables. 


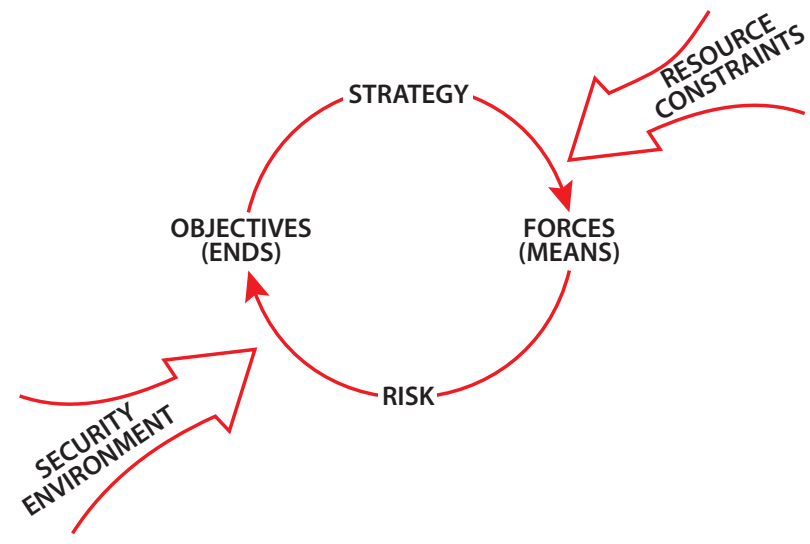

Figure 1

Bartlett Model

Source: BARTLETT-HOLMAN-SOMES 1995, 115.

\section{Objectives and ends}

By 2030, the fundamental objective is to guarantee the "necessary" (expected) security, which ensures political, economic and military stability. An adequate level of security is provided in the world when different threats do not endanger the "necessary" security of the world. Therefore, one of the most important preconditions for security is the implementation of effective and successful political, economic and military procedures and tasks. A predetermined level of security ensures that defence objectives can be achieved under any given circumstances.

\section{Security environment}

Analysing the security environment is the most important task, but it is also highly difficult. It is because emerging challenges can fundamentally change plans and objectives. The following factors should be considered in the next period:

- Climate change and related disaster control tasks

- Concentration of the population and related public security tasks

- Escalation of migration

- Terrorism and related organised crime

- Cyber warfare

- Uninterrupted world trade

- Armament competition between middle powers

- State failure ("rupture states") 


\section{Strategy}

The goal is to guarantee the "necessary" security within the alliance and beyond. At the policy level, the functioning and the effectiveness of existing international organisations need to be reviewed to ensure they can effectively respond to new challenges. With regards to the economy, international economic organisations will have a major role to play in reducing the likelihood of financial crises. This will be done by implementing new domestic economic policies and developing new forms of international cooperation. The future of the Alliance must be outlined, analysed and different scenarios must be drawn up on the basis of various uncertainties. The US leadership will continue to be important in NATO, but Europe must have to build the right forces. The NATO Response Force (NRF) will continue to play an important role, but the focus will be on crisis management, one of NATO's fundamental security tasks.

\section{Forces and Means}

Commonly used military methods include all elements of the armed forces that can act as a passive deterrent by carrying out certain activities such as:

- International peace-keeping and peace-building actions

- NRF applied abroad

- NRF applied in domestic areas (national level).

The use of NRF in domestic (NATO) areas are often criticized as an outdated practice, which will not be able to provide public safety. As a result, military operation will have a cooperative means to achieve desired public safety. The Special operations are playing an increasingly important role, they are typically used in Homeland in cooperation with specially trained organisations of similar purpose for law enforcement agencies.

\section{Resource constraints - "Less money"}

An important statement of the NIC report is that the next period will be characterised by the decline of the globalised economy and American hegemony. The conflicts and challenges will be increasingly difficult for leaders around the world. The governments need to deal with more than one problem at a time:

- social dissatisfaction due to poor economic performance and unequal distribution,

- the cost of law enforcement will rise, but it will not be able to meet the expected level of security. 


\section{Risk}

Every decision has the potential for failure, because environment variables cannot be precisely defined in advance. This applies equally to international or even domestic policy. Continuous assessment of the chances of success and failure are therefore very important in strategic planning. The constant pursuit of harmonising the changing elements of the strategy can reduce the risk of failure.

I see the issue of cooperation as the greatest risk factor, as the problem lies in the capability of cooperation between political, military and law-enforcement decision makers, and whether they are able to work together. I note that I set up this problem in 2012, but I received a clear refusal by the organisations concerned.

\section{General conclusions}

A key international trend is economic globalisation. The secure functioning of economy determines the welfare of humanity worldwide, because the safety and values of the participants of the global economy are very important both in the present and in the future. The standard of defence expenditures and responsibility have to be defined on the basis of a suitable risk analysis for state and/or owner.

The first section of this paper studies the effects of progressive globalisation that do not only pose a global security problem but also appear directly or indirectly at regional or local level. These effects can result in growing intrastate tension and possible natural disasters, climate change, non-functioning state, terrorism and organised crime and other conflicts in countries and regions. Therefore, closer cooperation with international organisations and institutions is needed in the critical zones.

The impact of the terrorist attacks on the world economy and its various sectors were investigated by economists. It was established that the incidental damages of the attacks were more severe than the amount of direct damage. In the design phase of the protection of critical infrastructure the "domino effect" should be taken into consideration, due to which the damages and impacts of the events can multiple and secondary, tertiary damage can occur.

NATO however remains the leader on if situation requires coherent use of our instruments, including, diplomatic, political, development, economic and trade co-operation, humanitarian, crisis response and civilian and military crisis management. I suggest that the military force and the companies involved in the implementation of the safety profile of the security problems must have safety certificate issued by the national authorities. 


\section{References}

BARTLETT, Henry C. - Holman, G. Paul - Somes, Timothy E. (1995): The Art of Strategy and Force Planning, Naval War College Review, Vol. 48, No. 2. 114-126.

Huntington, Samuel P. (1996): The Clash of Civilizations and the Remaking of World Order. New York, Simon \& Schuster.

JONES, John K. (2012): NATO's Relevance in the Twenty-First Century. Student academic research paper. Philadelphia, United States Army War College.

KUPCHAN, Charles. A. - KUPCHAN, Clifford A. (1995): The Promise of Collective Security. International Security, Vol. 20, No. 1. 52-61.

MorAn, Andrew (2015): The North Atlantic Treaty Organisation. In HougH, Peter MORAN, Andrew - PILBEAM, Bruce - STOKES, Wendy eds.: International Security Studies. Theory and Practice. London - New York: Routledge. 306-319.

NoETZEL, Timo - SCHREER, Benjamin (2009): Does a multi-tier NATO matter? The Atlantic Alliance and the process of strategic change. International Affairs, Vol. 85, No. 2. 211-226.

\section{Internet references}

Collective defence - Article 5 (2019). NATO. Available: www.nato.int/cps/en/natohq/ topics_110496.htm (Accessed: 25. 04. 2019.)

Global Trends - Paradox of Progress (2017). National Intelligence Council. Available: www.dni.gov/files/documents/nic/GT-Full-Report.pdf (Accessed: 20. 05. 2020.)

NASSAUER, Otfried (2001): Nuclear Sharing in NATO: Is it Legal? Berlin Informationcenter for Transatlantic Security. Available: https://www.bits.de/public/articles/ sda-05-01.htm (Accessed: 12. 04. 2019.)

NATO Cyber Defence (2016). NATO, Fact Sheet. Available: www.nato.int/nato_static fl2014/assets/pdf/pdf_2016_07/20160627_1607-factsheet-cyber-defence-eng. pdf (Accessed: 20. 05. 2020.)

NATO's nuclear deterrence policy and forces. NATO. Available: www.nato.int/cps/en/ natohq/topics_50068.htm (Accessed: 08. 04. 2019.)

NATO: Strategic Concepts. NATO. Available: www.nato.int/cps/en/natohq/topics_56626. htm?selectedLocale=en (Accessed: 12. 06. 2018.) 